\title{
Delayed Radiation Injury of \\ Gut-Exposed and Gut-Shielded Mice. \\ I. The Decrement in Resistance to \\ Continuous Gamma-Ray Stress
}

by

J. F. Spalding

R. F. Archuleta

J. E. London

J. R. Prine 
This work was supported by the US Energy Research and Development Administration, Division of Biomedical and Environmental Research.

Printed in the United States of America. A vailable from National Technical Information Service

U.S. Department of Commerce 5285 Port Royal Road Springfield, VA 22161

Price: Printed Copy $\$ 3.50$ Microfiche $\$ 3.00$

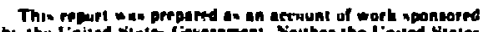

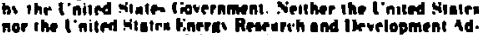
minietrulion mur uns of their emplowere, nor ans of theiv ron. tructors. subruntrartope. of thrir emplusere. maken ons

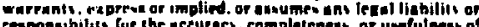

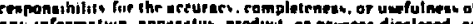

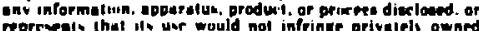

pienin. 
DELAYED RADIATIDN INJLRY OF CLT-EXPOSED MND GIT-SHIEILED MICE.

\section{THE DECREMENT IN RESISTANCE TO CONTINUULS GAMMA-RAY STRESS}

by

J. F. Spalding, R. F. Archuleta, J. E. London, and J. R. Prine

ABSTRACT

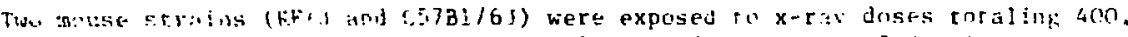

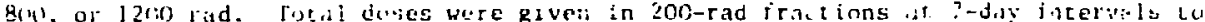

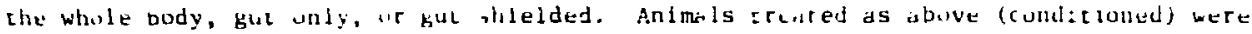
divided intu ? grmups to lirg a two-part Investigation. In Part II (tu be reported later), conditioned mice wert retained in a normal animal laboratory environment for whsiervatiun on lite spat dad listopachology at deach. In part 1 (reported here), $x-$ ray-condltioned and wntrol mice were subjected to a continuous gama-ray stress (challenge exposure) 28 days after the last $x$-ray dose. Delayed injury was measured as a reductlon in mean atter-survival (MAS) $t$ ime and was ubserved in whole-body, gutcunditioned, and gut-shitelded groups. The cause of death was atcributed to hemopoietic hypoplasia in all groups. Mas reduction in all conditioned groups in both strains was linear with dose within th: dase range used. Delayed injury per volume dose (measured as a reduction in Mas) was independent of the tissue initialiy conditioned with an acute duse of $x$ rays. Thus, delayed injury per unit weight of gut issue exposed was equal to that ff either whole-bory or gut-shielded radiation injury. Comparative weight loss ubservations during the continuous gamna-risy challenge exposure revealed a decretnent in metabolic processes as: jelated with body weight maintenance. This decrement was seen in all $x$-ray-conditioned groups.

1. INTRiL: ZC: ION

That different thsues of the manmalian system exiabit radiosensitivity it different degrees was reported nearly 8 decades agu. ${ }^{\text {i }}$ experimental investigations on the comparative effects (particularly acute etfects) of partial-body irradiation were done by a number of investigators dating to as early as 1920. 2-f Nithough some work has been doue on late effects or delayed radiation injury of partial-body exposure, ${ }^{7-11}$ llfe shortening and response to general stress of mamals with partial-body exposure in which "Il hone tissue was either exposed or slitelded have not been reported.

A more thorough understanding of the general site "ritin, nature, and magnitude al delayed radiation Injury is of interest in radiation cherapy, ivil defense, milltary, and manned space misstion planning. Radiation exposures $t a$ be dealt wlth by all the above would be predomianty partial- rather than whole-body. This report deals with the results of part I of a two-part investigation designed to obtain intormation on the parameters of late effects.

\section{METHUIS AND MTERIALS}

Two hus dred sixty-lour strdin $C 57 B 1 / 6.1$ and $37 \mathrm{t}$ strain $\mathrm{KF} / \mathrm{J}$ virgin iemale mice 3-months-old ber used. Mice or each strain were divided randomly into 11 groups of appro..smately 24 mice eath. The various groups were exposed to $x$-ray conditioning doses of 400 , 800 , or 1200 rad to the whole body. gut only, or tutal body wh gut shielded, as shown in rable 1 . Condition:ng doses were given while the mile were anestherized ( $\sim 125 \mathrm{mg}$ Nembutal/g body weight) il. plattic jigs (Fig. Il in ino-rad 1 rait luns at i-day intervils.

A typial expossure schedule for radiatint therapu is $2(M)$ rad/day, 5 days/bk. We used 7 dasi between expusuris to permic the actumulation in 
TABLE I

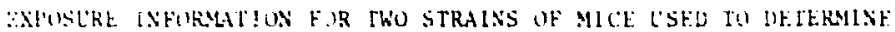

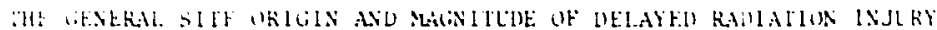

\begin{tabular}{|c|c|c|c|c|c|c|c|}
\hline 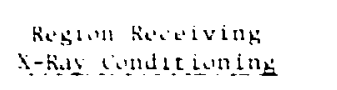 & 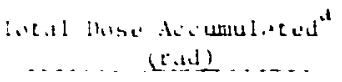 & $\begin{array}{l}\text { Number al } \\
\text { c5: }\end{array}$ & 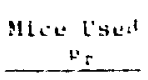 & $\begin{array}{l}\therefore \mathrm{UI} \\
\mathrm{LS} \mathrm{Z}\end{array}$ & $\begin{array}{l}\text { Mortality } \\
\text { Ri }\end{array}$ & Budy & $\begin{array}{l}\text { Wetiphe litit } \\
\cdots(-1)\end{array}$ \\
\hline Contril (no anesthestal) & 1 & 24 & 24 & 0 & 0 & & (1) \\
\hline whtrul (nnestlestiod) & 0 & 24 & 24 & 0 & 1) & & "1 \\
\hline hinle body & $\begin{array}{l}.00 \\
\text { sou } \\
\text { bin) }\end{array}$ & $\begin{array}{l}\therefore \rightarrow \\
\therefore \rightarrow \\
\therefore \rightarrow\end{array}$ & $\begin{array}{l}24 \\
32\end{array}$ & $\begin{array}{r}0 \\
8 \\
79\end{array}$ & $\begin{array}{l}u \\
\dot{4} \\
4\end{array}$ & & $\begin{array}{l}100 \\
1001 \\
1011\end{array}$ \\
\hline liul $\times 31:$ & $\begin{array}{l}\therefore x 1 \\
8(100 \\
1200\end{array}$ & $\begin{array}{l}\therefore 4 \\
24 \\
24\end{array}$ & $\begin{array}{l}\therefore 4 \\
\therefore 4 \\
2:\end{array}$ & $\begin{array}{r}8 \\
12 \\
17\end{array}$ & $\begin{array}{r}24 \\
0 \\
11\end{array}$ & & $\begin{array}{l}25-26 \\
25-26 \\
25-26\end{array}$ \\
\hline Gut shoeleded & $\begin{array}{l}+(1) \\
\text { bou } \\
1200\end{array}$ & $\begin{array}{l}\therefore 4 \\
\therefore \rightarrow \\
24\end{array}$ & $\begin{array}{l}\therefore \\
\therefore \\
\therefore 4\end{array}$ & $\begin{array}{l}8 \\
8 \\
3\end{array}$ & $\begin{array}{l}11 \\
11 \\
4\end{array}$ & & $\begin{array}{l}74-75 \\
74-75 \\
74-75\end{array}$ \\
\hline
\end{tabular}

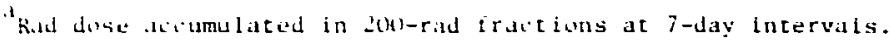

bercont lethality from acute duses priar to challenge exposure.

Buebl serains are represented by these tigures.

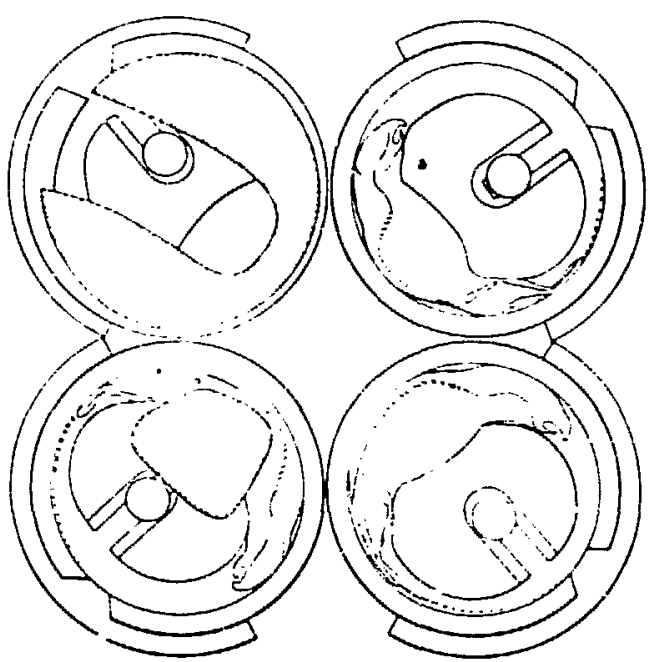

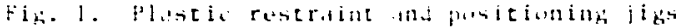
usced to expusie or thield muse fut tissue dur ing x-rav condit forninte deses. The

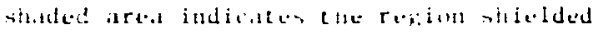
wit? t. 35 man if le.11.

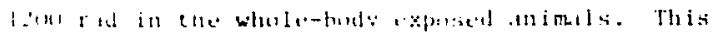
i-das period is approximately 1 recurery hall time

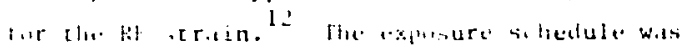

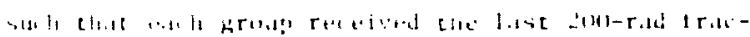

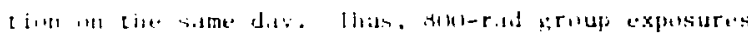

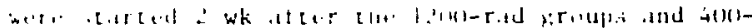

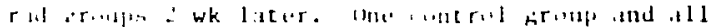

condicioned groups were aneschetized at the time each 200-rad iration was given, whecher or not the group was scheduled for exposure. Thus, regardless of the cutal conditioning dose recelved, each group was given the sante number of anest sial treatments 111 at the same time. A setond contral group which rectived no $x-r$ dy conditioning dose also received nut trentment with anesthesid.

Exposure arrangentents tor the $x$-ray condition-

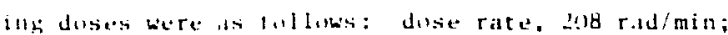

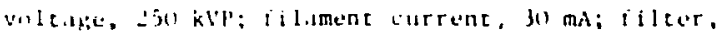

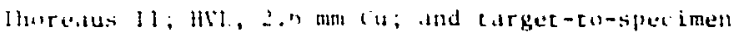
d: t.1nce, J:0 mas. Dase rates were mealsured with

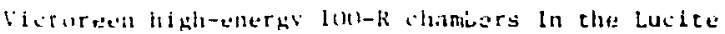

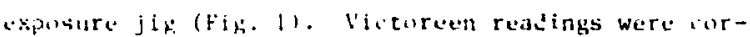
rectest fur bolrumel i, pressure ard temperature and

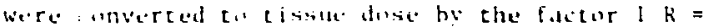

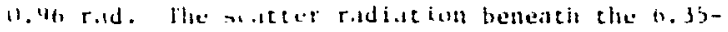

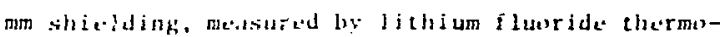

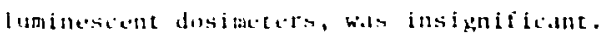

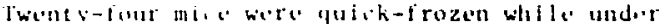

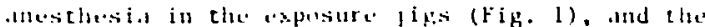

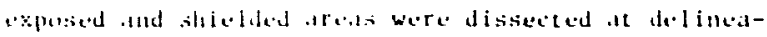

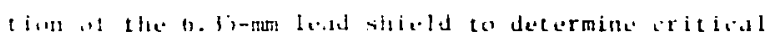

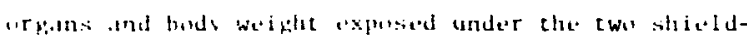

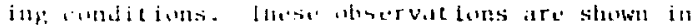
1.11!1e. 11 . 
TABLE 11

WE ILYI: UF BODY, ORLIAN, OR TISSUE EXPUSED IO X-RAY CONDITIONING DOSES

Whole Kldneys

Body Scunach Gut Bone Kight Left Liver Spleen Pelt

liur shiereded

$\begin{array}{lllllllll}7 i & 4 & 2 & 100 & 100 & 77 & 53 & 15 & 66\end{array}$

Git Exposed

$\begin{array}{lllllllll}26 & 96 & 96 & 0 & 0 & 23 & 47 & 85 & 34\end{array}$

in percent.

Twenty-eight days after the last 200-rad $x$-tay conditioning dose lapproximately 4 times the recovery half time (RT ${ }_{50}$ ) of geriain RF micel, ${ }^{12}$ all cond $1-$ timod and inntrol groups were placed in a ${ }^{60}$ Co hamfit-rav environment fur invariant challenge exposure's until death. The mice were pusitfoned around the surce ... A mean radius wf 2.3 m where chey accumulated approximately is rad/each 24 h of exposure. The dose rate was such that animals in the center of the exposure cage accumulaced $54 \mathrm{rad} /$ each $\therefore$ h of exposise.

The mice weye weighed priol to and after the conditioning exposure schedule, after the $2 \mathrm{H}$-day rewerery perind, and perindically durirg the invirtant diallenge exposure. rour thice (randomly selacted at each bleedingl were bled pribr to the

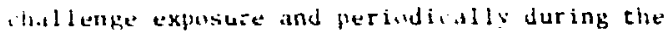
firtunat-ray iballenge.

Mite were housed b/cage un woud shavings in stainless stuel box-type cages $(125$ by 200 by $300 \mathrm{~mm})$ during condicioning expesures and recovery. They were housed $8-10 /$ cage in plist ic cages measuring 170 b. 280 hy 1211 monting the concinuous gamma-ray dhallenge exposure. Rockland-Teklad Mouse and Rat biet and water were provided ad libicum. and clean hottles and cages were provided twice weekly.

\section{RE.SUI.TS AND BISCUSSION}

Sume acute lethality acturred during the conditioning exposures. The peroent mortality during $x-r .1 v$ conditioning and the 28 -day period iollowing the last lou-rad conditioning frottion is shown in lahle i. Seraln c.57 mice were genterally mote sensitive to the acute conditioning exprsures than wete strain kF mice.
Body weight changes in control animals with the anesthesia were sumewhat different than sham cantrols with anesthesia (Figs. 2 and 1 ), Fur this ruason, all comparaifive data in this report are based on anesthetized sham control mice. Cumparar ive weight changes during $x$-ray conditioning, recovery, and gamma-ray challenge periods art shuwr for whole-body condicioned strains RF and $\mathrm{C} 57 \mathrm{miru}$ in Figs. 4 and 5, respectively.

The conditioning exposures adversely af ferted weight gain in both mouse strains, and the effect was influenced by the number of 200-rad conditioning fractions given. Strain C57 showed a more unifurm response (Fig. 5) in this effect than the RF strain (Fig. 4). Although body weights were depressed (according to conditioning dose) on the day f,1llowing the last 200-rad conditioning fraction, a $11 x$ ray-conditioned groups reached or exceeded control body weight levels after the 28-day recovery periud (figs, \& and 5). This comparative weight respunse was less discinct in gut-shielded conditioned and gur-conditioned wice. However, overrecovery (as measured by body weighe) was observed in all gruups receiving either partial-or whole-body conditioning exposures. Comparative body weights in all $x$ ray-conditiones groups in both strains indicated that any injury detrimental to metabolic processes involved in normal tissue proliferation and growth was uf a transient nature and that the mice hat compl-tely recovered 28 days after the last $2(1)-r a d$ $x$-ray condicioning dose (Figs. 4 and 5). However, this wi i apparently not true as body weight in $x-$ rily-cunditioned gruups subjected to the same fiamilatray challenge dose rate (approximately $50 \mathrm{rad} / \mathrm{dal}$ ) as nonconditioned controls dropped more sharply than in controls. With the exception of the $400-\mathrm{rad}$ whale-body challenged gruup in RF mice (Fig. 4), the drop in body weight during the challenge exposure was directly related $t$ the size of the $x$-ray conditioning dose. To a lesser degree, this was $t$ rue in woth bone- and gut-conditioned groups (Flgs. i, 7 , 8 , and 9). Although weight changes were less pronounced in both bune- and put-conditioned groups Juring the conditioning period, hoth of these partial-body-exposed groups showed more overesarer during the z8-diy recovery period than whole-bidsconditioned animals. 


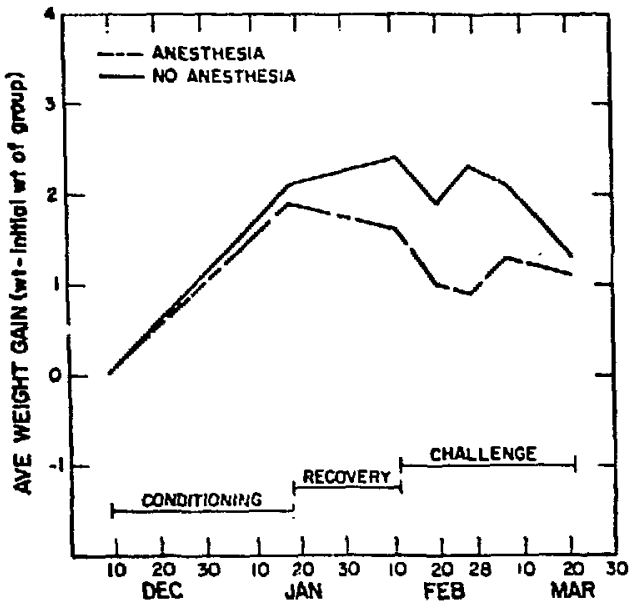

Fig. 2. Comparative weight changes of control mice with and without anesthesia during $x$-ray conditloning and recovery periods and during gama-ray challenge exposure (strain RF/J mice).

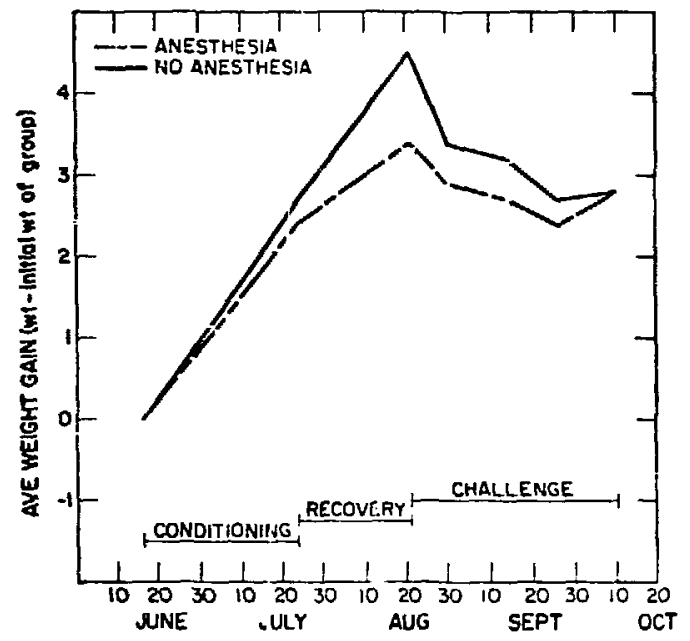

Fig. 3. Comparative weight changes of control mice with and without anesthesia during $x$-ray conditioning and recovery periods and during ganma-rav challenge exposure (strain C57BI/6J mict.

It is interesting that this phystological response from delayed radiation injury is observed in animals with bone cissue tocally exposed and totally shitelded. The dose-dependent decrement in metabolic processes assuciated with body weibht me nitenance during a gentral physiological stress observed here suggests a persistent radiatiun lesion of a rather nunspecifi, nature and is an thd point not known to have been reported previnusly. Studies by Kuzinal

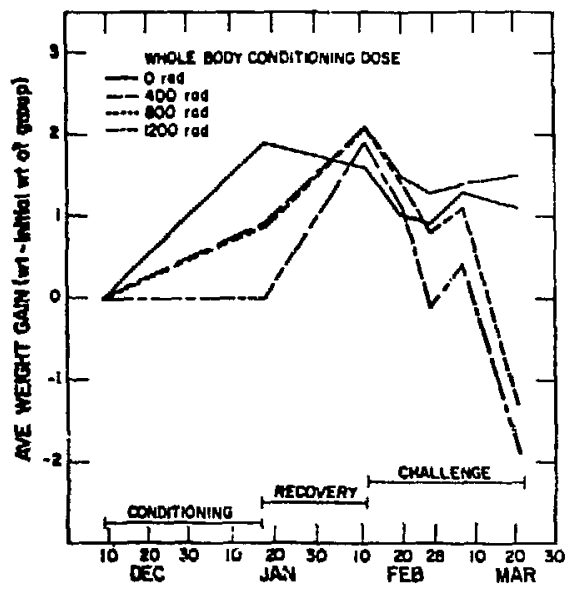

F1g. 4. Comparative weight changes of whole-bodyconditioned strain RF/J mice during $x$-ray conditioning, recovery, and gamma-ray challenge exposure.

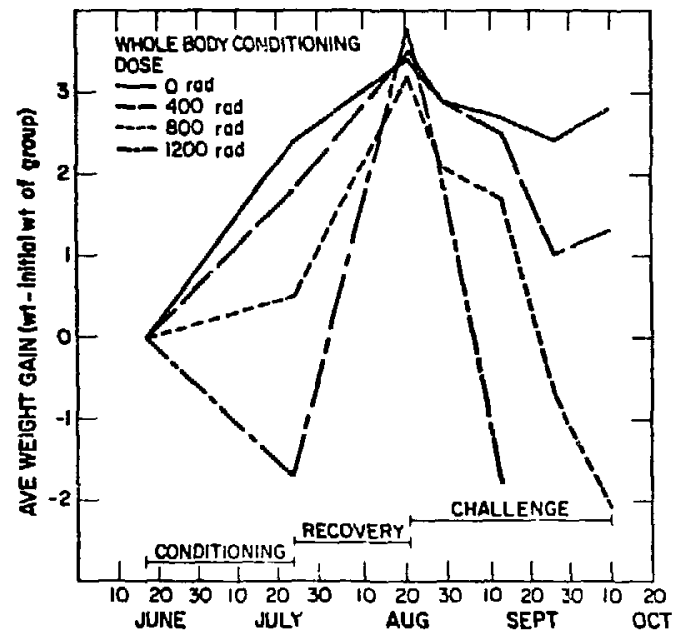

Fig. 5. Comparative weight changes of whole-bodyconditioned strain C57Bl/6J mice during $x$-ray conditioning, recovery, and gamma-ray challenge exposure.

on the hydrolytic function of the intestines of mice for 30 days following $600 \mathrm{R}$ to the whole body or with one shin shielded shored shin-shielded animals to have substantially less disturbance in enzyae actfvity and less weight loss than whole-body-exposed mice. Thus, nonirradiated hemopoietic tissue not directiy associated with the intestines appears capable of a sparing effect on radiation-induced injury to the intestinal digestive proctss; 


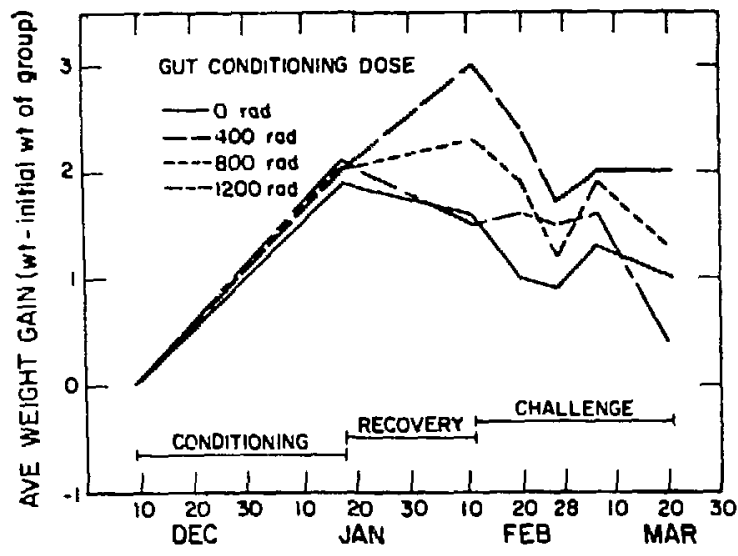

Fig. 6. Comparative weight changes of gutcondicioned strain RF/J mice during $x$-ray conditioning, recovery, and gamma-ray challenge exposure.

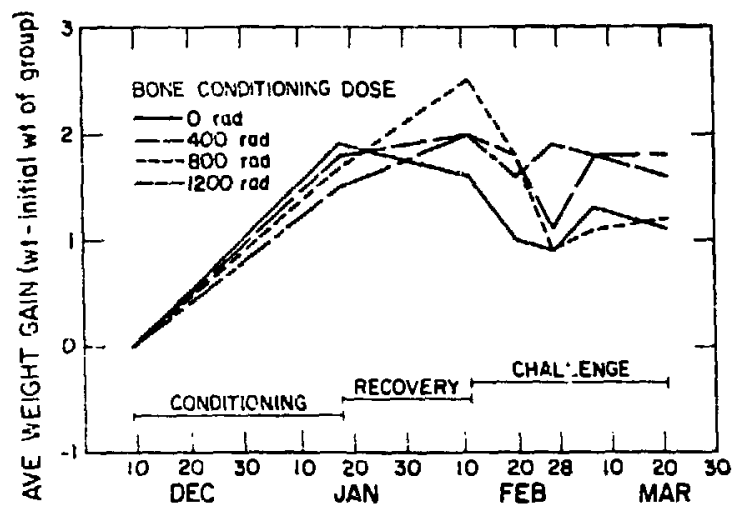

Fig. 7. Comparative weight changes of boneconditioned strain RF/J mice duriag $x$-ray conditioning, recovery, and gamma-ray challenge exposure.

cunversely, these observatic's suggest that irradiated hemopoietic tissue distant to the intestines can adversely affect the metabolic function of the unirradiated gut. The nacure of this decrement is not ipparent but may be due to an intercellular injury information transfer factor (IITTF) which affects the production and/or transport of digestive enzymes during the cephalic, gastric, or incestinal phise of gastric juice production. Whatever the nature of the decrement may be, it does appear to be quite persistent.

Peripheral blood values of control and conditioned gruups 28 days after $x$-ray condicioning are tabulated in Table III. White blood cell (WBC) counts in RF/J conditloned anlmals remained

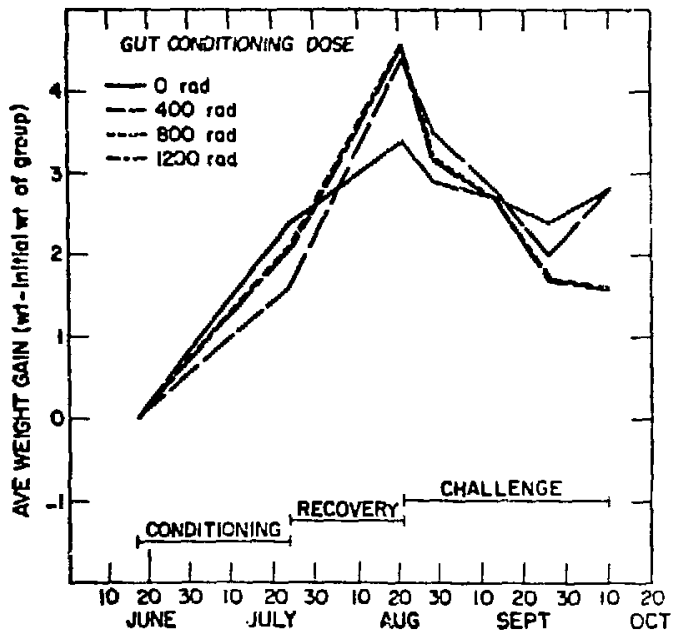

Fig. B. Comparative welght thanges of gutconditioned scrain C57Bl/6J mice during $x$ ray condlcloulng, recovery, and gamma-ray challenge exposure.

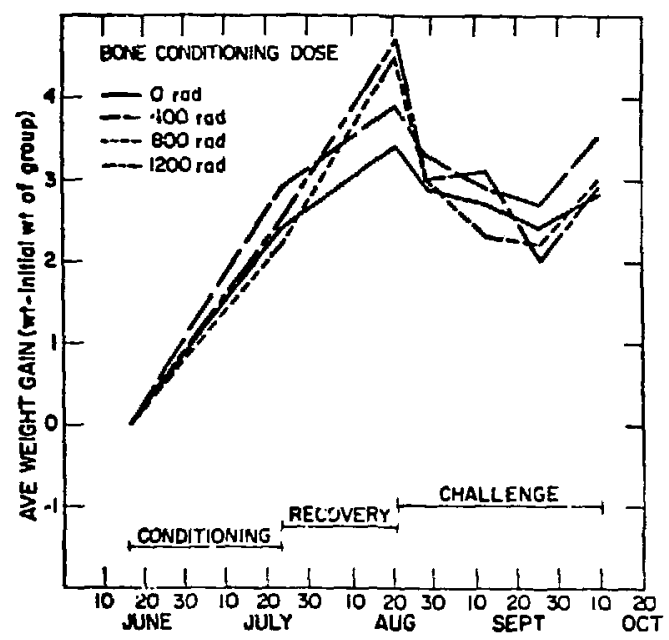

Fig. 9. Comparative weight changes of boneconditioned strain C57Bl/6J mice during $x-$ ray conditioning, recovery, and gamma-ray challenge exposure.

depressed below concrol values and were generally dose-related in whole-body and bone-exposed groups. In strain C57 mice, the gut-exposed groups showed essentially no depression in WBC count, while their strain RF counterparts showed substantial WBC count depressions (Table III). Packed cell volume (PCV) in most of the conditioned mice of both strains was slightly depressed 28 days after the last $200-r a d$ conditioning exposure. However, only the wholebody-condicioned groups of the C57 strain showed 
TABLE III

PACKF.D CELL VOLUME AND WHITE BLOOD CELL COUNTS

OF AREA X-RAY-CONDITIONED MICE 28 DAYS AFTER CONDITIONING

\begin{tabular}{c}
$\begin{array}{c}\text { Region Recelving } \\
\text { X-Ray Conditioning }\end{array}$ \\
\hline
\end{tabular}

Packed Cull Volume Mean \% cuntrol

\section{Strain C57B1/6J}

$\begin{array}{lrr}\text { Sham control } & 0 & 9414 \\ \text { Whole body } & 400 & 5078 \\ & 800 & 4425 \\ & 1200 & 4274 \\ \text { Gut unly } & 400 & 8802 \\ & 800 & 9796 \\ & 1200 & 9379 \\ \text { Gut shielded } & 400 & 7635 \\ & 800 & 6140 \\ & 1200 & 5223 \\ \text { Scrain RF/J } & & \\ \text { Sham control } & 0 & 11999 \\ \text { Wnole body } & 400 & 6149 \\ & 800 & 58.33 \\ & 1200 & 5459 \\ \text { Gut only } & 400 & 6725 \\ & 800 & 9082 \\ & 1200 & 6797 \\ \text { Gut shielded } & 400 & 7965 \\ & 800 & 4036 \\ & 1200 & 3655\end{array}$

0
$46.2^{a}$
$53.0^{a}$
$45.0^{a}$

$6.5^{a}$
4.1
0
$18.9^{a}$
$34.8^{a}$
$55.5^{a}$

$\begin{array}{cc}54.6 & 0 \\ 50.4 & 7.6^{\mathrm{a}} \\ 48.5 & 11.2^{\mathrm{a}} \\ 44.8 & 17.9^{\mathrm{a}} \\ & \\ 52.8 & 3.3^{\mathrm{a}} \\ 54.6 & 0 \\ 54.0 & 1.1^{\mathrm{a}} \\ 54.1 & 1.0^{\mathrm{a}} \\ 54.0 & 1.1^{\mathrm{a}} \\ 52.8 & 3.3^{\mathrm{a}}\end{array}$

${ }^{a}$ Less than control.

more than minor changes, and in these groups the depressim in PCV was dose-dependent.

The end point utilized to meet the primary objective in part I of this investigation was l..e comparative response of conditioned and contro, mite to a continuous whole-body physiological challenge of in $\sim 50-\mathrm{rad} /$ day gamma-ray environment. Persistent injury in the whole-body-, gut-, and boneconditioned mice was determined by comparative survival times in the gama-ray field. Mean aftersurvival (MAS) and reduction in MAS, uncorrected and corwcted fur body weight exposed (integral dost or per volume dose), are listed for strain C57BL/6J in Table $1 \mathrm{~V}$ and for strain $R F / J$ in Table $V$.

Strain C57 mice were more sensitive to the acute conditioning regime than were strain RF mice (Table I). However, this stritin difference in radiuresistance was reversed with the invarianc challenge exposure (Tables $I V$ and $V$ ). St rain $C j I$

controls survived approximaceiy 25 days longer than strain RF controls and, with the exception of the 1200-rad whole-body-exposed groups, only $20 \%$ of the mice in this group survived the conditioning exposures (Table 1). Mll doses and arta-conditiuned strdi: c57 mile were more tolerant of the challenge exposure than strain Rf mice. Mean llfe sfrans of the $657 \mathrm{Bl} / 6 \mathrm{~J}$ and $\mathrm{RF} / \mathrm{J}$ mouse strains are reported tu be 693 and 452 days, iespectively. ${ }^{14}$ Airhough the degree of response to the garma-ray challenge was different in the two strains, the nature of the response was quite similar. Survival curves for conditioned and control mice during continuous ganmaray exposure at $50 \mathrm{rad} / \mathrm{day}$ are shown for stain $R F / J$ mice in $F i g . ~ l o$ and for strain c57bl/6.j mice in Fin. 21 .

Yein a fer-survival (MAS) times of whole-bodyand bone-conditioned animals were clearly dependent on conditioning dose, with similar survival rurve? 
TABLE IV

MEAN AFTER-SURV:VAL (MAS) TIME OF X-RAY-CONDITIONED

C57/6J STRAIN MICE DURING INVARIANT GAMMA-RAY STRESS

\begin{tabular}{|c|c|c|c|c|c|}
\hline \multirow[b]{2}{*}{$\begin{array}{l}\text { Condltioning } \\
\text { Treatment }\end{array}$} & \multirow[b]{2}{*}{$\begin{array}{r}\text { Dose } \\
\text { (rad) }\end{array}$} & \multirow[b]{2}{*}{$\begin{array}{l}\text { MAS } \\
\text { (çays) }\end{array}$} & \multicolumn{3}{|c|}{ Reduction in MAS } \\
\hline & & & $\begin{array}{l}\text { Per } 100 \mathrm{rad} \\
\text { of Exposure }\end{array}$ & $\begin{array}{c}\text { Corrected to } \\
\text { Whole-Body Exposure }\end{array}$ & Mean \\
\hline Sham control & 0 & $: 00.4$ & $n$ & 0 & 0 \\
\hline Whole body & $\begin{array}{r}400 \\
800 \\
1200\end{array}$ & $\begin{array}{l}66.0 \\
51.2 \\
26.1\end{array}$ & $\begin{array}{l}4.30 \\
6.15 \\
6.19\end{array}$ & $\begin{array}{l}0 \\
0 \\
0\end{array}$ & 5.55 \\
\hline Gut only & $\begin{array}{r}400 \\
800 \\
1200\end{array}$ & $\begin{array}{l}99.1 \\
86.4 \\
83.8\end{array}$ & $\begin{array}{l}0.32 \\
1.75 \\
1.38\end{array}$ & $\begin{array}{l}1.30 \\
7.00 \\
3.52\end{array}$ & 4.60 \\
\hline Bone shielded & $\begin{array}{r}400 \\
800 \\
1200\end{array}$ & $\begin{array}{l}87.2 \\
77.0 \\
59.0\end{array}$ & $\begin{array}{l}3.30 \\
2.92 \\
3.45\end{array}$ & $\begin{array}{l}4.40 \\
3.90 \\
4.60\end{array}$ & 4.30 \\
\hline
\end{tabular}

TABLE V

MEAN AFTER-SURVIVAL (MAS) TIME OF X-RAY-CONDITIONED

RF/J STRAIN MICE DURING INVARIANT GAMA-RAY STRESS

\begin{tabular}{|c|c|c|}
\hline $\begin{array}{c}\text { Conditioning } \\
\text { Treatment }\end{array}$ & $\begin{array}{r}\text { Dose } \\
\text { (rad) } \\
\end{array}$ & $\begin{array}{l}\text { MAS } \\
\text { (days) } \\
\end{array}$ \\
\hline Sham control & 0 & 74.33 \\
\hline Whole body & $\begin{array}{r}400 \\
800 \\
1200\end{array}$ & $\begin{array}{l}61.79 \\
41.00 \\
31.33\end{array}$ \\
\hline Gut .nly & $\begin{array}{r}400 \\
800 \\
1200\end{array}$ & $\begin{array}{l}71.79 \\
66.58 \\
64.80\end{array}$ \\
\hline Bone shielded & $\begin{array}{r}400 \\
800 \\
1200\end{array}$ & $\begin{array}{l}59.29 \\
55.04 \\
44.63\end{array}$ \\
\hline \multicolumn{3}{|c|}{ 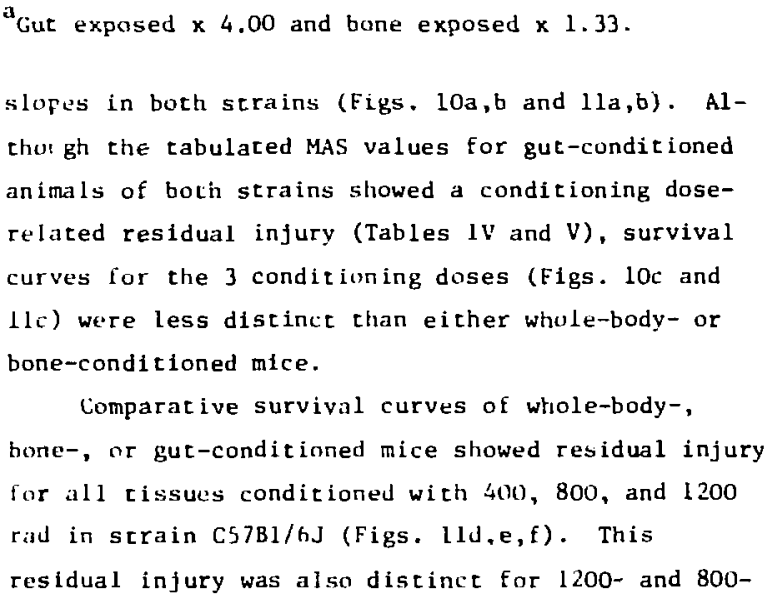 } \\
\hline
\end{tabular}

\begin{tabular}{ccc}
\multicolumn{3}{c}{ Reduction in MAS } \\
$\begin{array}{c}\text { Per 100 rad } \\
\text { of Exposure }\end{array}$ & $\begin{array}{c}\text { Corrected to } \\
\text { Whole-Body Exposure }\end{array}$ & Mean \\
0 & 0 & 0 \\
3.14 & 0 & \\
4.17 & 0 & 3.63 \\
3.58 & 0 & \\
0.64 & & \\
0.97 & 2.56 & \\
0.79 & 3.88 & \\
3.76 & 3.16 & \\
2.41 & & \\
2.48 & 5.01 & 3.84 \\
& 3.21 &
\end{tabular}

rad conditioning doses in strain $R F / J$ mice, but at the 400-rad level, gur-conditioned mice were similar to controls and the bone- and whole-bodyconditioned mice were different from controls but similar to each other (Figs. IOd,e,f).

Gut-conditioned animals included exposure to $25-26 \%$ of the body tissue by weight, and bone exposures included $74-75 \%$ (Tabie II). When reduction in MAS in gur- and bone-conditioned mice was corrected to whole-body exposure (1.ffect/unit weight of tissue exposed), the residual radiation-induced injury of gut-exposed mice was similar in amount to 

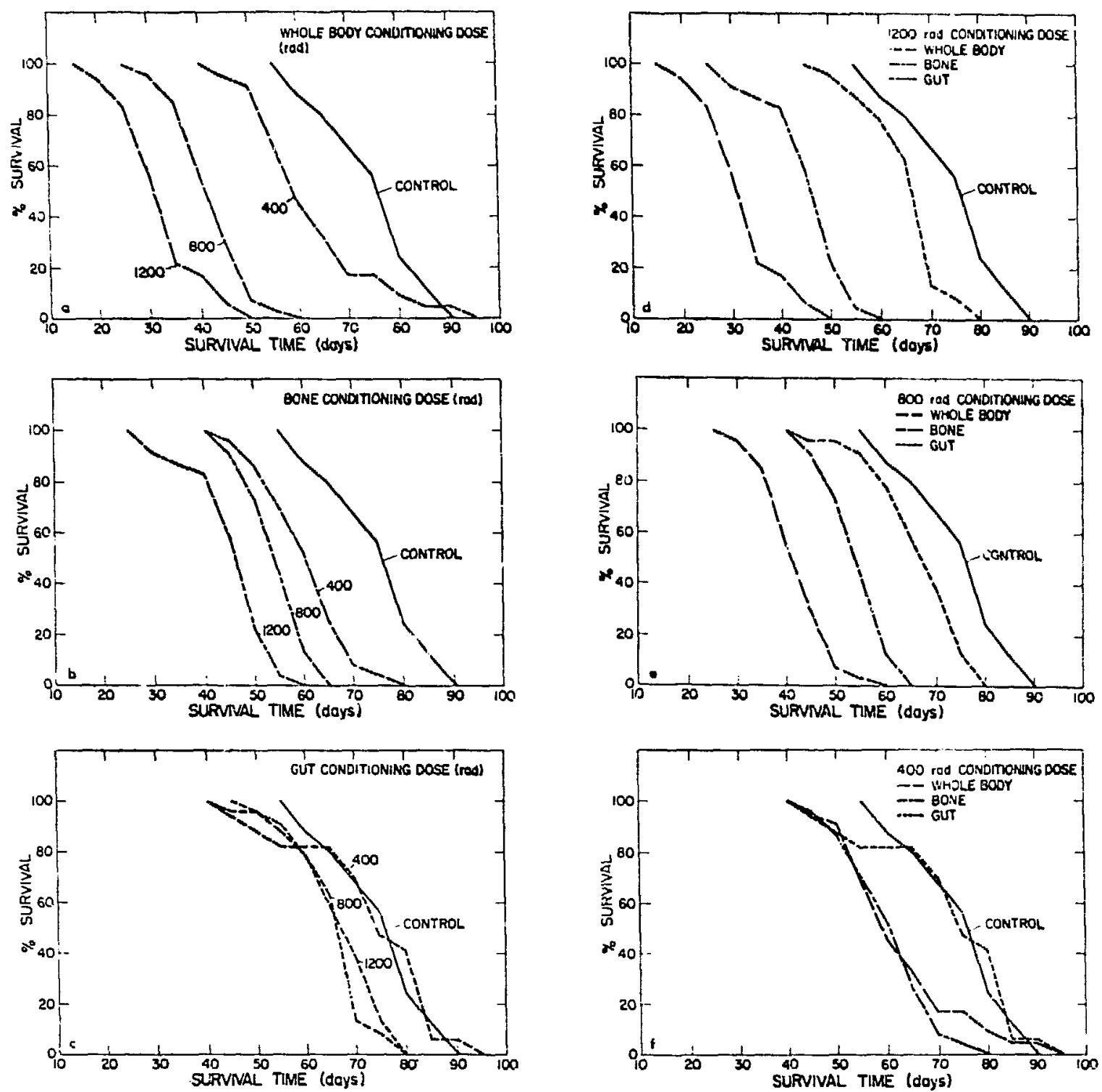

Fig. 10. Comparative survival curves of control and $x$-ray-conditioned strain RF/J mice during a continuous $50 \mathrm{rad} /$ day gamma-ray challenge exposure: (a) control and whole-body condictoning doses of 400 , 800 , and $1200 \mathrm{rad;}(\mathrm{b})$ control and bone condicioning doses of 400,800, and 1200 rad; (c) control and gut conditioning doses of 400,800 , and $1200 \mathrm{rad}$; (d) control and 1200-rad conditioning dose to the whole body, bone, and gur; (e) control and 800-rad conditioning dose to the whole body, bone, and gut; and (f) control and 400-rad conditioning dose to the whole body, bune, and gut.

that incurred in bone-conditioned mice. Furcher, the combined reduction in MAS of gut- and boneconditioned animals approached that of whole-bodyconditionad strain C57P.:/6J mice (Table IV) and approximaced the whole-body-condicioned mice in strain RF/J (Table V).

Area shielding studies in which all bone tissue is exposed to ionizing radiation (condictoned) or shielded have not been done previuusly. However, intuitively one might expect bone conditioning to provoke greater persistent injury/unit exposed than gut-conditloned animals. Mice ${ }^{15}$ and ritts ${ }^{11}$ with $x-$ ray conditioning to the lower half of the body exhibited about twice as much life shortening as animals with $x$-ray conditioning to the upper half of the body. Life shortenlng/volume dose in the 

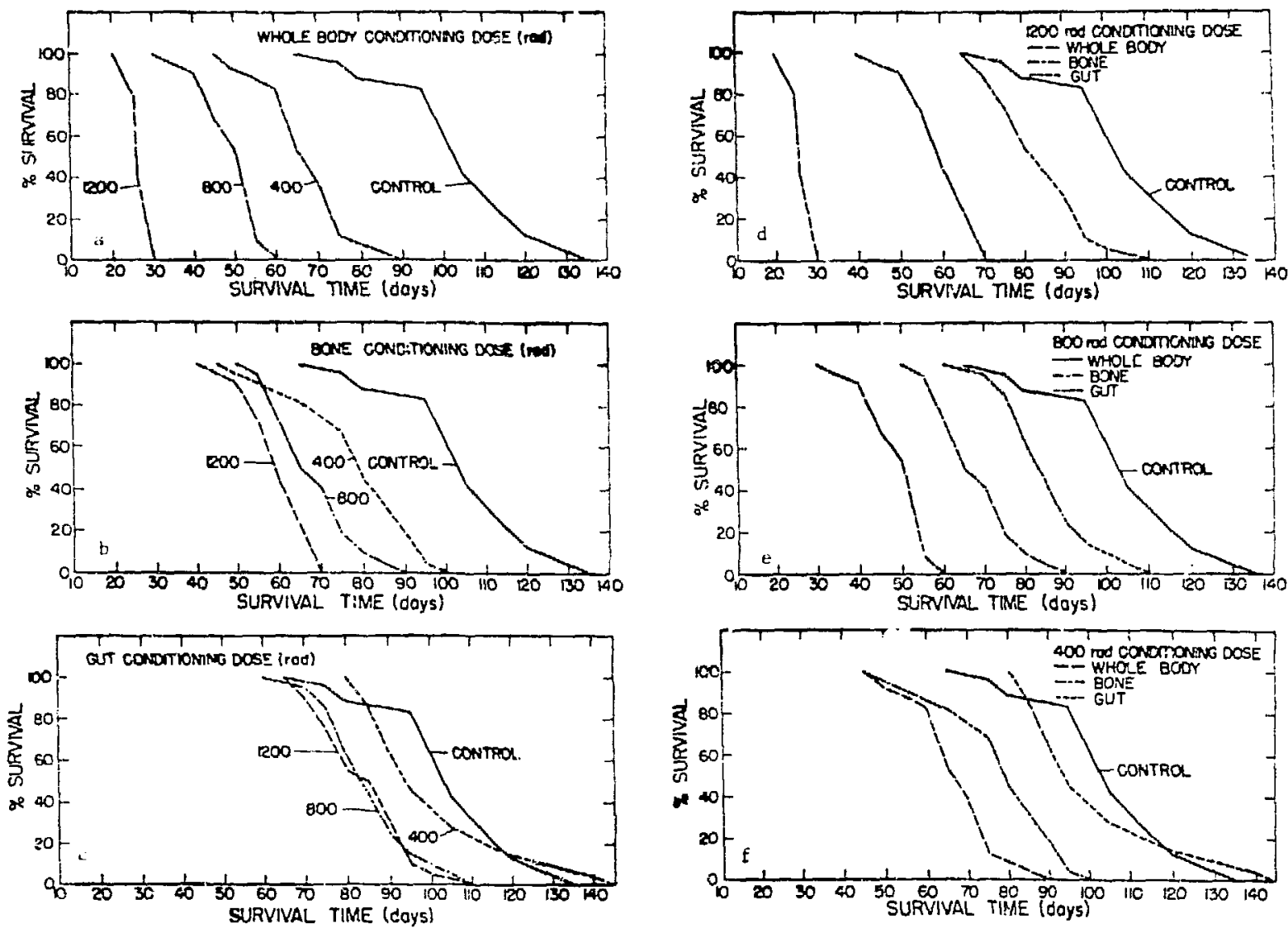

Fig. ii. Luparative survival curves of control and $x-r a y-c o n d i c i o n e d ~ s t r a i n ~ C 57 B l / t b$ mice during a lonfinuous 50 rat day gama-rav challenge exposure: (a) control and whole-bod: conditioning dust of whl, bul, and $1200 \mathrm{rad}$ (b) zontrol and bone conditioning doses of 400 , 800 , and 1200

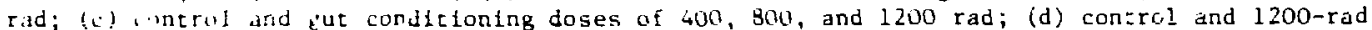
inditiuning d.sie tu the whole body, oone, and gut; (e) rontrol and goo-rad crnditloning dose to the whitix iony, bone, and gut; and (i) control and 4 on-rad conditioning dose to the whole body, bunt, and gut.

whole body, head, trunk, and lower body (pelvis, legs, and tail) ut mice exposied to a single $x$-ray dose of $400 \mathrm{R}$ was iepurted by Satu e: al. le to be groatest in head-exposed mice and least (not signiticantly less than controls) for mice exposed tc the lower body. The test end point in this and other partial-body irradiation studites was life shortening in a rormal laboratory environment. Thus, resulcs on the origin, magnicude, and nature of the effects may not be pertinent to observations in this study which utilfzed a reduction in Mas during a continuous physiological stress provided by a 50 radiday gamaray environment. The physiological mechanisms involved in or measured by the two end points may be quite ditferent.
The results of part I of this investigation way appear to conflict with earlier residsal injury studies on partially shielded mice and/or rars. However, the shieldinb and $x-r a y$ conditioning techniques and residual injury measurement end point combination used here are different from other studies and make data comparison difficult. Part II oi this isvestigation, in which life shortening in a normal laboralory environmen: is being used to stuoy radiation effects trom exposures described in Table I, has been destgned to explore the comparative nature of the effects observed by these two end points. 


\section{ACKNOWLEDGMENTS}

The cooperation of $R$. $H$. Wood in performing grosa post-morian and histopathology preparations and 0 . S. Johnson for $x-$, gamma-, and lithium fluoride thermoluminescent dosimetry is gratefully apprectated.

\section{REFERENCES}

1. D. Kalsh, "Deep Tissue Traumatism From Roentgen Ray Exposure," Brit. Med. J. 2, 272 (1897).

2. W. Den1s, C. L. Mareln, and M. Aldrich, "A Study of the Relative Toxlc Effects Produred by Regional Radiation," Am. J. ifed. Sc1. 160, 555559 (1920).

3. V. P. Boni, M. N. Swlft, A. C. Allen, and M. C. Fishler, "Sensitivity of Abdomen of Rat to $X-$ Irradiation," Am. J. Roentgenol. 161= 322-330 (1950).

4. J. C. Crook, E. V. Hulse, C. H. Mulvey, and G. J. Neary, "The Acure Effects of Partial Body Beta Irradiation of Mice," Brit. J. Radiol. 31, 477-485 (1958).

5. H. A. Blair, "Acute Lethality of Partial Body In Relation to Whole Body Irradiation," Untversity of Rochester Atomlc Euergy Project report $\mathrm{GR}-462$ (1950).

6. C. L. Hansen, 5. M. Michaelson, and J. W. Howland, "The Blological Effects of Upper Body XIrradiation of Beagles," University of Rochester Atomlc Energy Project report UR-580 (1960).

7. R. F. Kallman and H. I. Kohn, "L1fe-Shortenlag by Whole and Partial Body X-Irradiation in Mice," Science 128, 301-302 (1958).

3. G. E. Cosgrove and A. C. Upton, "Some Delayed Effects to Partial Body Irradiation In Mice of the RF Strain," Int. J. Radiat. B1ol. 4, 97103 (1961).
9. A. Dunjlc, J. Malsin, P. Maldague, and M. Maisin, "Incidence of Mortality and Dose-Response Relationship following Partial-Body X-Irradiation of the Rat," Radlat. Res. 12, 155-166 (1960).

10. W. J. Quinlan, K. Scheer, R. W. Neidlinger, S. M. MAchgelson, and J. W. slowland, "Late Manifestations or whole and Partlal body Iontzing Radiation in the Dog: A Two Year Sumary," University of Rochester Atomle Energy Project report UR-609 (1962).

11. A. L. Carsten and J. R. M. Innes, "The Effects of Partial Body Irradiation on Delayed Responses," Arn. N. Y. Acad. Sc1. 114, 316-327 (1964).

12. J. F. Spalding, T. T. Truj1llo, and W. L. LeStourgeon, "Dependence of Rate of Recovery from Acute Gama-Ray Exposure on S1ze of the Conditioning Dose," Radiat. Res. 15, 378-389 (1961).

13. V. A. Kuzina, "Influence of Partial Shielding of the Bone Marrow and the Functional Size of the Intestinal Eptehellum in Mice after Irradiation," Kadioblologia (Moscow) 12(4), 4248 (1972), English translation.

14. J. M. Yuhas, "Genertc Control of Aging and Radiation-Induced Life-Shortening in Mice," The Jackson Laboratory report NYO-3314-15 (August 1969).

15. I. U. Boone, G. Trafton, L. Conklin, and R. C. White, "Effect of Partial and Whole Body XIrradiation on Iffe Span and Tumor Incidence of CF Mice," Los Alamos Sclentific Laboratory report i.A-2445-MS (1960), pp. 274-284.

16. F. Sato, S. Tsuchthash1, and N. Kawashima, "Life-Shortening of Mice by Whole or Partial Body X-Irradiation," J. Radiat. Res. 14, 115119 (1973). 